\title{
The Dirt on "White Slavery": The Construction of Prostitution Narratives in Early Twentieth-Century American Newspapers
}

Erin Gallagher-Cohoon

\begin{abstract}
The paper "The Dirt on 'White Slavery': The Construction of Prostitution Narratives in Early Twentieth-Century America" analyses the development of white slavery discourses in Progressive Era newspapers, reform books and trial records. White slavery involved both gendered and racialized fears of coercive prostitution. These prostitution narratives are used to uncover early twentieth-century American perceptions of appropriate femininity, inherent female weakness, and the sexual threat of racial and ethnic minorities.
\end{abstract}

Prostitution is considered the oldest profession in the world and was and often still is seen as one of society's social ills. During the Progressive Era in the United States of America, there were fears that not only was prostitution a growing industry of sin, but that women were being coerced into becoming prostitutes. This so-called "white slave" traffic was the forerunner of the modernday sex traffic. Discourses in the newspapers, in reform books and in trial records can be used to uncover early twentieth-century American perceptions of appropriate femininity, inherent female weakness, and the sexual threat of racial and ethnic minorities. The language surrounding white slavery, found in these original sources can help the historian answer questions regarding sexual norms and the social control of female bodies. Defining the term "white slavery" is of primary importance because, even at the time, different social actors used varying definitions to their own advantage. White slavery narratives were used by many different social groups to control urban women, especially immigrants, even as the construction of a pure, white, female body was used to patrol the color line. Within American newspaper accounts during the Progressive era, especially between 1900 and 1920, the topic of prostitution was broached in several ways. There were fears of coercive prostitution, "white slavery", and as a result there was a renewed vigor in efforts of the social control of female bodies and sexuality. For example, the social purity movement attempted to completely eradicate prostitution through legal, political and social reforms. ${ }^{1}$ Prostitution was framed, especially by morality reformers such as Jane Addams, as a uniquely female problem and so the study of how prostitutes were viewed and talked about can shed some light on middle-class sexual norms and on assumptions of female weaknesses.

While the language of prostitution and "white slavery" are clearly seen in newspapers and other primary sources, it is important to distinguish the two terms. Definitions of the white slavery trade were and still are debated, as will be seen later, but in its most basic form, white slavery was a form of prostitution that was economically and physically coercive. To what extent any form of prostitution is consensual is a question for other scholars to undertake, but let it just be said for now that "white slavery", like present day sex trafficking, is differentiated by its severity and cruelty. ${ }^{2}$ Perhaps more importantly, however, "white slavery" was the coercive prostitution of white Anglo-American women. Though the term was sometimes enlarged to include

\footnotetext{
${ }^{1}$ Cynthia M. Blair, I've Got to Make My Livin': Black Women's Sex Work in Turn of the Century Chicago (Chicago: University of Chicago Press, 2010), 6.

${ }^{2}$ See, for example, Arthur L. Stinchcombe and Laura Beth Nielsen, "Consent to Sex: The Liberal Paradigm Reformulated," Journal of Political Philosophy 17, no. 1 (March 2009): 66-89, doi: 10.1111/j.14679760.2008.00306.x.
} 
immigrants or African American women, it generally implied a racial divide between the purity of white women and the sexual immorality of others.

The other difficulty in differentiating white slavery from other types of prostitution, is the difficulty in analysing how widespread a phenomenon it was. While newspapers and trial records may have disproportionately reported cases of white slavery, it is equally important that evidence of the violence and coercion in prostitution and human trafficking is not dismissed. "White slavery" as a term that differentiated white prostitutes from others was constructed, but this does not negate the fact that prostitutes, regardless of ethnicity and race, often worked in conditions akin to slavery and were sometimes forced into sex work.

This being said, the white slavery debate was popularized in newspapers for many reasons, and the political manipulation of this phenomenon must be taken into account. Available historical records demonstrate the wide variety of socio-political uses of white slavery. For example, charges of corruption against political leaders were often bolstered by claims that they supported, or at least failed to prevent, the traffic in women in their jurisdiction. ${ }^{4}$ Also, when many contemporaries themselves did not explicitly see a difference between prostitution and white slavery, it is impossible to say with any certainty the number of women who were drugged, imprisoned, indentured, raped, or transported illegally into a life of prostitution.

The historical investigation of the white slavery phenomenon lends itself to several other methodological problems. For example, the historian must also be careful not to over generalize regarding attitudes towards sexuality or prostitution. Among those of differing class, race, gender, and age, what was considered appropriate or inappropriate expressions of sexuality were far from homogenous. As gender historian Elizabeth Clement successfully demonstrates in her social history Love for Sale: Courting, Treating, and Prostitution in New York City, 1900-1945, working-class views about and relationships with prostitutes did not always neatly fall into line with middle-class reforms. ${ }^{5}$ Clement studies the evolution of the social category of "charity girls" who traded sexual favors for gifts and entertainment, within the context of changing sexual norms and the repression of vice, including prostitution. She states, for example, that charity girls consciously distanced themselves from the monetary exchange of prostitution and so opened up new physical and moral spaces for working class women. ${ }^{6} \quad$ While Clement studies the larger sexual culture of early twentieth-century United States of America, other historians have concentrated directly on issues related to the "white slavery" question. Even within the historiography on white slavery, there is some difficulty in defining the term. The social historians Francesco Cordasco and Thomas Monroe Pitkin, for example, explore the intersections between fears of an international white slave trade and the development of immigration laws in the United States. They concentrate on port cities, the importation of foreign women and the ethnicities that were considered, by reformers, to be particularly prone to the

\footnotetext{
${ }^{3}$ Brian Donovan and Tori Barnes-Brus, "Narratives of Sexual Consent and Coercion: Forced Prostitution Trials in Progressive Era New York City," Law \& Social Inquiry 36, no. 3 (Summer 2011): 600, doi: 10.1111/j.17474469.2011.01244.x

4 "Bingham Furnished White Slavery Data," New York Times, October 31, 1909.

${ }^{5}$ Elizabeth Alice Clement, Love for Sale: Courting, Treating, and Prostitution in New York City, $1900-1945$ (Chapel Hill: University of North Carolina Press, 2006), 16.

${ }^{6}$ Clement, Love for Sale, 64.
} 
trade. In this context, Jewish men, they argue, were thought to procure young girls already in the United States, and the French were thought to import professional prostitutes. ${ }^{7}$

In contrast to Cordasco and Pitkin, the sociologist Brian Donovan sees the discourse directed toward white slavery as embedded in narratives of the urbanisation of early twentieth-century northern cities. A common story ran as follows: a white country girl goes to the city either because of a false promise of marriage or in search of employment and finds herself trapped by a white slaver who is often an immigrant. ${ }^{8}$ In Donovan's reading of white slavery, both in White Slave Crusades and his co-authored article with Tori Barnes-Brus, trial records and popular fiction both point to the use of these narratives to construct race and gender identities. For these two selections, white slavery is an issue that must be understood in the context of urbanization, and the influx of women in public spaces.

The concentration on the racial undertones in white slavery narratives as found in Donovan's work is also important to historians who study African American issues. The historian Cynthia Blair writes of the marginality of black prostitutes within the Chicago vice district and how their status was also linked to the progressive reform movement. She analyzes, for example, how middle-class fears for white virtue, in the form of fears about "white slavery", influenced the urban sex trade. This was due in part because of the anti-prostitution activism of organizations such as the Committee of Fifteen. ${ }^{9}$ She also argues that black middle-class reformers co-opted the discourse around white slavery to challenge racist views held by many white reformers regarding black women's sexuality. ${ }^{10}$ In a similar vein, historians Janet Beer and Katherine Joslin note that the language around white slavery was used in the 1910s in Chicago to differentiate it from "black" slavery and that it focused institutional attention on the traffic in white, especially native-born, women. This, despite the fact that, in reality, there was more evidence of a traffic in racial minorities. ${ }^{11}$

Within this vast historiography on prostitution and white slavery, it is possible to chart the context in which the white slavery debate gained ground. Progressive Era United States, described as the period between the 1890s and the 1920s, was marked by urbanization, women entering the workforce and shifts in the racial composition of many northern cities, such as New York and Chicago. It was also a time of changing courtship practices. The young working class were moving away from the parental gaze and towards new urban amusements such as dance halls and moving picture shows as the setting of their courtships. ${ }^{12}$ At the same time, the late nineteenth-century and early twentieth-century saw a growing emphasis on the repression of vice in the form of purity crusades, which had an enormous impact on brothel prostitution. For example, police raids and changes in land use around the entertainment districts led to a decline

\footnotetext{
${ }^{7}$ Francesco Cordasco and Thomas Monroe Pitkin, The White Slave Trade and the Immigrants: A Chapter in American Social History (Michigan: Blaine Ethridge Books, 1981), 12.

${ }^{8}$ Brian Donovan, White Slave Crusades: Race, Gender, and Anti-Vice Activism, 1887-1917 (Chicago: University of Illinois Press, 2006), 18.

${ }^{9}$ Blair, I've Got to Make My Livin', 136.

${ }^{10}$ Blair, I've Got to Make My Livin', 191.

${ }^{11}$ Janet Beer and Katherine Joslin, "Diseases of the Body Politic: White Slavery in Jane Addams' "A New Conscience and an Ancient Evil" and Selected Short Stories by Charlotte Perkins Gilman," Journal of American Studies 33, no 1 (April 1999): 6, http:www.jstor.org/stable/27556532.

${ }^{12}$ Clement, Love for Sale, 4.
} 
in brothel prostitution and a subsequent rise in streetwalking and other forms of the commercial sex trade. ${ }^{13}$

It is within these interconnecting socio-cultural changes that the white slavery debate, as seen in the newspapers of the time, can be analyzed. With the decline of brothel prostitution and the moral panic over decadent sexuality, white slavery became a focal point for many different social fears about the place of women in the workplace and in the public sphere. The unique presentation of white slavery, especially given its potential for sensational portrayals of the sexual ruin of innocent women, was politically influential at the time. ${ }^{14}$ But what were these representations and what can it tell us about the broader American sexual culture?

First of all, the problem of white slavery was discussed, in newspapers, in gendered language. Prostitution in general was seen as a uniquely female problem and reformers sought to protect young girls from the evils of white slavers. For example, Rose Livingston was a reformer and suffragette who worked in New York's Chinatown, patrolling and attempting to liberate young white prostitutes who sometimes resisted her protection. ${ }^{15}$ In essence, the white slavery discourse was embedded in assumptions about appropriate female behavior and the construction of a Victorian ideal of white femininity.

Issues of patriarchy arise in one of two ways, either the socio-economic oppression of women is seen as a primary cause of white slavery, or an inherent female weakness is construed as the problem. Two letters to the editor in The San Francisco Call demonstrated this debate. In one, W. Chandler conflated white slavery and prostitution in general and asserted that low wages were not the cause of a white slave trade but rather that "feminine vanity and a consequent desire for jewels, ease and fashionable apparel [were] responsible". ${ }^{16}$ In response, a woman named Frances Minton wrote to the newspaper and asserted that Chandler had misunderstood the situation. According to Minton, there was an important distinction to be made between white slavery and prostitution, and white slavery was based on economic conditions. She differentiated between the old evil of prostitution and the "commercial industry, which deliberately cheats, traps, and drugs even, unsuspecting girls ". ${ }^{17}$ This contestation of Chandler's description of white slavery was, interestingly, made by a woman, not a man. It is important to remark how, even here in a small column in the newspaper, the question of definition was paramount. If white slavery was the same as the prostitution industry, as Chandler asserted, then contemporary working conditions could not explain its existence whereas inherent female characteristics could. On the other hand, if white slavery was a new phenomenon, as described by Minton, then low wages and working conditions in the unique context of American industrialization, was a logical explanation. In essence, semantics mattered.

Other newspaper accounts such as an August 16, 1916 article of the confessions of Yushe Botwin, a white slaver, alluded to the question of feminine vice. The white slaver was quoted as

\footnotetext{
${ }^{13}$ Clement, Love for Sale, 86-87.

${ }^{14}$ Ruth Rosen, The Lost Sisterhood: Prostitution in America, 1900-1918 (London: The John Hopkins University Press, 1982), 112.

${ }^{15}$ Mary Ting Yi Lui, "Saving Young Girls from Chinatown: White Slavery and Woman Suffrage, 1910-1920," Journal of the History of Sexuality 18, no. 3 (September 2009): 402, doi: 10.2307/20542730.

${ }^{16}$ W. Chandler, "A Man's Viewpoint," San Francisco Call, March 25, 1913.

${ }^{17}$ Frances Minton, "A Woman's Viewpoint," San Francisco Call, March 30, 1913.
} 
having said "Some cost more; some less. But they're all alike", implying that all women could be bought for the right price. So, despite his confession of having lured away children and auctioned women, it seems that his role was less violent kidnapper than cold-hearted seducer, two common roles often attributed to white slavers in both newspapers and morality tracts. ${ }^{18}$ This relates once again to the ambiguity of the definition of the white slave trade, and to its re-appropriation of older captivity and seduction stories. For example, earlier versions of the same trope included stories about the abduction of white frontier women by Native Americans. ${ }^{19}$ Letters and other newspaper articles are not the only sources that dealt with the issue of white slavery. Middleclass reformers also debated whether prostitution, coerced or otherwise, was the result of economic inequality or whether it was due to female weakness. A moral reformer, Jane Addams wrote her 1914 account of the white slavery epidemic in Chicago and struggled with this issue. On one hand, she asserted that prostitution was a "hideous choice between starvation and vice". Ten pages later, she accused girls of using economic pressure as an excuse. Addams instead described "the immediate causes... [as]her love of pleasure, her desire for finery, or the influence of evil companions". ${ }^{20}$ Thus, Addams acknowledged economic inequality as an important social issue, but still maintained negative assumptions regarding female behavior. Diverging somewhat from Minton's explanation of white slavery, these various accounts demonstrate that women were not uniform in their denunciation of the social ills that encouraged various forms of prostitution. While white slavery and prostitution more generally were constructed as a gendered issue in newspapers and in reform manuscripts, they were also seen as a racial or ethnic issue. The term itself differentiated the slavery of "whites" from the black slavery of the antebellum period. ${ }^{21}$ White slavery in many ways embodied the intersections between race and gender because sexual deviancy itself was racialized in popular accounts.

The link between sexual immorality and ethnic or racial minorities manifested in several ways. For one, when looking at the ethnicity of those involved in the trade, white slavers such as Yushe Botwin, were often assumed to be immigrants. ${ }^{22}$ Purity reformers, such as Addams, also brought up the question of who the victims of the white slave trade were. Many of her case studies, for example, were immigrants. ${ }^{23}$ Newspapers also mentioned the prevalence of immigrants, especially the Chinese, as young prostitutes engaged in the white slave trade. ${ }^{24}$ Chinatown was thought to be an area of particular importance to the traffic of immigrant women because of the disparity in gender ratios in the community. ${ }^{25}$ Though the most common trope of a white slave victim remained a native-born, white country girl, there were increased concerns that the immigration laws were further victimizing foreign white slaves through deportation. ${ }^{26}$ While many viewed white slavery as the result of immigration, there were those, like the infamous

\footnotetext{
18"Saw White Slavery as Mere Business," New York Times, August 16, 1916.

${ }^{19}$ For more on this subject, see Donovan, White Slave Crusades, 17.

${ }^{20}$ Jane Addams, A New Conscience and an Ancient Evil (New York: The Macmillan Company, 1914), 49; Addams, A New Conscience, 59.

${ }^{21}$ For further discussion on the comparison between coercive prostitution and slavery, see Addams, $A \mathrm{New}$ Conscience, 3-7.

22"Saw White Slavery as Mere Business," New York Times, August 16, 1916.

${ }^{23}$ See, for example, Addams, A New Conscience, 20-21.

24"Slavery of Chinese Girls," San Francisco Call, May 22, 1899.

${ }^{25}$ Neil Larry Shumsky, "Tacit Acceptance: Respectable Americans and Segregated Prostitution, 1870-1910," Journal of Social History 19, no. 4 (Summer 1986): 666, http://www.jstor.org/stable/3787983; for further discussion on the moral reform movement in Chinatown, see Lui, "Saving Young Girls," 393-417.

${ }^{26}$ Addams, A New Conscience, 34.
} 
anarchist Emma Goldman, who denied the existence of a white slave traffic and viewed prostitution as a home-grown American institution. Goldman was a controversial radical feminist and anarchist who lectured on issues such as birth control and free love and was, herself, eventually deported in $1919 .{ }^{27}$ According to her analysis, prostitution was simply one choice on a spectrum created by a society that sexually and economically oppressed women. In fact, she lectured on the similarities between prostitution and marriage, both, in her mind, forms of sexual barter. For example, she stated, "[n]owhere is woman treated according to the merit of her work, but rather as a sex. It is therefore almost inevitable that she should pay for her right to exist... with sex favors". ${ }^{28}$ She maintained that there was no proof of a systematic traffic in women from overseas but did describe how poverty and limited economic choices drove some women to prostitution, especially in the American context which emphasized excessive displays of wealth. ${ }^{29}$ Meanwhile, other reformers, such as Rose Livingstone, were also challenging the patriarchal government and argued that women would only be protected through a major social change such as suffrage. ${ }^{30}$ Despite these examples of dissenting views, policy-makers of the day continued to frame the white slavery debate as an issue of immigration and the foreign pollution of Anglo-American morals. ${ }^{31}$ At the same time, another source of increased racial tension was the turn-of-the-century migration of African Americans to northern cities, and the resulting possibility of interracial sexuality. ${ }^{32}$ Addams, despite her racist views on African American sexuality, acknowledged the relationship between Blacks living in poor tenement houses and the often disproportionate numbers in "deviant" lifestyles. According to Addams, a combination of poverty, unstable family life resulting from a history of slavery, and a lack of restraint combined to make African Americans particularly prone to immorality. ${ }^{33}$ If white women were often cast as the chaste victims of the white slave trade, immigrants and African Americans were seen as the sexual threats. ${ }^{34}$ In contrast, middle-class African American leaders would rely on the construction of female vulnerability and innocence to circumvent ideas of black promiscuity and include their community members under the protection of the reform movement. ${ }^{35}$

Unfortunately, this was not extended to include African American men who were still vilified as sexual aggressors. While African American reformers were attempting to protect Black prostitutes, interracial relationships were still viewed with hostility by many Americans. One case that caught international attention was Jack Johnson's arrest and conviction. This was a result of a law passed in 1910, "The White Slave Traffic Act". It was commonly known as the "Mann Act", and, in an attempt to control the interstate traffic of women, it prohibited the transportation of women across state lines for immoral purposes. ${ }^{36}$ Unfortunately for Jack Johnson, it was often used to persecute men travelling with women in consensual relationships.

\footnotetext{
${ }^{27}$ Alix Kates Shulman, "The Most Dangerous Woman in the World," in The Traffic in Women and Other Essays on Feminism (New York: Times Change Press, 1970), 5.

${ }^{28}$ Emma Goldman, "The Traffic in Women," in The Traffic in Women and Other Essays on Feminism, ed. Alix Kates Shulman (New York: Times Change Press, 1970), 20.

${ }^{29}$ Goldman, "The Traffic," 28.

${ }^{30}$ Lui, "Saving Young Girls," 394-395.

${ }^{31}$ For further discussion, see "Many Changes in the Immigration Laws," New York Times, December $23,1901$.

${ }^{32}$ Blair, I've Got to Make My Living', 2-3.

${ }^{33}$ Addams, A New Conscience, 118-119.

${ }^{34}$ Donovan and Barnes-Brus, "Narratives of Sexual Consent," 605.

${ }^{35}$ Blair, I've Got to Make My Livin', 191.

${ }^{36}$ Christopher Diffee, "Sex and the City: The White Slavery Scare and Social Governance in the Progressive Era," American Quarterly 57, no. 2 (June 2005): 419, http://www.jstor.org/stable/40068272.
} 
And, to add to his misfortune, Johnson was not only Black but a celebrity within the African American community.

Even in Canadian newspapers, Jack Johnson's name appeared numerous times in July of 1910. On July 4th, the Edmonton Daily Bulletin ran a front cover story on the "Negro Champion" who won a boxing match against the only previously undefeated heavyweight champion of the world, a white man, James Jeffries. ${ }^{37}$ The following two days saw a tremendous amount of attention given to the "colored man" who beat the "White Man's Idol". The fight was so widely broadcast and stirred such antagonism that there were reports of race riots and lynching in Washington, in West Virginia and in Texas, among others. Often framed as the fault of African Americans who were "encouraged by Johnson's victory" and "in several assaults used knives" or attempted to "shoot up the town in honor of Jack Johnson's victory", racial animosity would continue to follow Johnson long after the fight. ${ }^{38}$

Two years later Johnson would once again be the figure of headlines as he was charged under the Mann Act for transporting Lucille Cameron over state lines. His case demonstrated to what extent the Mann Act failed to protect those it was instituted to protect, and instead was used for racially motivated politics. Despite the fact that it was Lucille Cameron's mother who accused Johnson of kidnapping her daughter, there was no evidence to support that the young prostitute was forcibly taken across state lines. ${ }^{39}$ But she was a "19 year old white girl" and Johnson, the "negro pugilist" had a reputation for crossing the color line, even to the point of marrying white women. ${ }^{40}$

Raising the specter of white slavery once again, The San Francisco Call reported that, as a result of the Johnson case, there was an investigation in Chicago of a brothel that specialized in "procuring white girls for well to do negroes". ${ }^{41}$ Whether this club actually existed or not, the Mann Act was meant to target the traffic of women, not acts that, considered immoral or not, were consensual. As Johnson's lawyer would later argue to the Supreme Court, a woman should not be treated as a marketable good placed under the jurisdiction of policies related to interstate commerce. $^{42}$ Despite this, and despite the fact that Johnson would later marry Lucille Cameron, he would be charged under the Mann Act.

Like the racism that motivated the Johnson case, fears of miscegenation were also portrayed in popular culture during the Progressive Era. One film in particular brought the debate about interracial sexuality to the forefront in 1915. Birth of a Nation was the most profitable film of the era, and was both intensely popular and intensely controversial. ${ }^{43}$ It was portrayed as a historic account of the Civil War and the Reconstruction era in the United States. It described the rise of the $\mathrm{Ku}$ Klux Klan as a justified, even noble attempt by disenfranchised white men to protect white women from black men. ${ }^{44}$ In one scene, for example, the Southern belle, Elsie Stoneman,

\footnotetext{
37"Johnson, Negro Champion, Won in Fifteenth Round," Edmonton Daily Bulletin, July 4, 1910.

38"Prize Fight Stirs Racial Feeling," Edmonton Daily Bulletin, July 5, 1910.

39 "Johnson Threatens Lawyer with Violence," Edmonton Daily Bulletin, October 22, 1912.

40 "White Girl Turns on Jack Johnson," San Francisco Call, October 23, 1912.

41 "White Girl Turns on Jack Johnson," San Francisco Call, October 23, 1912.

42 "Supreme Court Gets Jack Johnson's Plea," San Francisco Call, December 18, 1912.

${ }^{43}$ Melvyn Stokes, D.W. Griffith's The Birth of a Nation: A History of "The Most Controversial Motion Picture of All Time" (Oxford: Oxford University Press, 2007), 3.

${ }^{44}$ Stokes, D.W. Griffith's The Birth of a Nation, 6.
} 
is pursued by the mulatto politician, Silas Lynch, who imprisons her and attempts to force her to marry him. ${ }^{45}$ Those who critiqued it, especially the National Association for the Advancement of Colored People (NAACP), saw it as encouraging racial prejudice and disunion between whites and blacks. ${ }^{46}$

But, despite this obvious racism, it was far from an unpopular film, even among the politically and diplomatically elite, such as President Woodrow Wilson. In fact, the film quoted from Wilson's own historical work A History of the American People, demonstrating how entrenched racism, especially sexual segregation, remained. Wilson's earlier description of the Reconstruction followed the same plot as Birth of a Nation. It was argued that newly freed slaves were left with little guidance and were taken advantage of by "carpet baggars". The Southern white man was, in turn, politically crippled and turned to vigilantism to protect his family. ${ }^{47}$ Using history to justify segregation, Wilson's argument was embedded in a deep nostalgia for the American South. Racism, and white female vulnerability in the face of assumed African American sexual violence, were entrenched in the American twentieth-century political system. White slavery was simply one manifestation of this.

While the white slavery discourse was embedded in issues of gender and race, a more in depth analysis of the language used to describe white slavery can help to explain why this topic was so influential during the Progressive Era in the United States. As has already been seen, newspapers described the "social evil" of the "importation of women...for immoral purposes" and called for a moral reawakening that would not only cease the white slave trade but also effectively deal with political corruption. ${ }^{48}$ Tammany Hall, a New York political organization that monopolized power during the period, was seen as particularly problematic and an increased attention to the issue of vice and corruption was evoked during election periods. ${ }^{49}$ This demonstrates to what extent the white slave issue was political because, as a symbol of vice and governmental impotence, it was used to bolster or undermine political power.

To transmit their political message, the white slave trope of a country girl deceived by a promise of marriage and handed over to a brothel was quite blatant in many newspaper accounts. Popular culture of the time was fixated on the sexual slave, as can be seen by films such as The Traffic in Souls and novels such as The House of Bondage. Newspaper ads and book reviews subsequently brought their message to an even wider public. ${ }^{50}$ As a result, a common narrative about the white slave emerged and, alongside this familiar characterization of the naive girl tricked by the shadowy figure of the procurer, there is also, once again emphasis placed on economic conditions.

\footnotetext{
${ }^{45}$ Stokes, D.W. Griffith's The Birth of a Nation, 24.

${ }^{46}$ Stokes, D.W. Griffith's The Birth of a Nation, 130.

${ }^{47}$ Lloyd E. Ambrosius, "Woodrow Wilson and The Birth of a Nation: American Democracy and International Relations," Diplomacy and Statecraft 18, no.4 (2007): 690, doi. 10.1080/09592290701807168; Woodrow Wilson, "Reconstruction," in A History of the American People (New York: Harper \& Brothers Publishers, 1902), 5: 1-114.

${ }^{48}$ "Nation-Wide Fight on White Slavery," New York Times, March 24, 1912; "The Business of Vice," New York Times, October 24, 1909.

49"The Business of Vice," New York Times, October 24, 1909.

${ }^{50}$ For example, " 'The House of Bondage': 'White Slavery' as it Presents Itself to a Writer of Fiction," New York Times, September 17, 1910.
} 
These popular narratives, however, were not exclusive to the United States. Despite Goldman's assertions that prostitution resulted from unique American circumstances, very similar stories were found elsewhere in the English-speaking world. British moral tales such as The Miseries of Seduction told an early nineteenth-century version of the white slave narrative in which a hardworking girl, Lucy, is seduced by her employer's son and is later abandoned. Lucy, unable to return to her family after her fall from purity, ended up a prostitute. ${ }^{51}$ This shows that the twentieth-century American white slave drama was based, in part, on older nineteenth-century narratives of seduction, and that parallel stories were being constructed in Britain. ${ }^{52}$

Another example of British moralization regarding prostitution is found in a twentieth-century memoir of a London prostitute, Sheila Cousins. This book would implement some of the same elements of seduction and coercion in its narrative, even though Cousins would insist that becoming a prostitute was her own choice. This re-appropriation of agency is overshadowed by her often tragic stories of men who seduced her or, later, offered her a way of surviving through sexual barter. Cousins' story followed the traditional line of a white slave narrative, beginning with her as an innocent working-class girl. She resisted, at the beginning of her tale, the sexual overtures of her male friends until, lured by two strangers, she was locked in a room and raped. Following the loss of her virginity, she felt there was no sense in resisting other men and so began her gradual downfall into prostitution. ${ }^{53}$

Neither Sheila Cousins nor Lucy in The Miseries of Seduction are white slaves in the narrow sense of the term. They are not, for example, forced into a brothel by a procurer. Both of their stories, however, share many of the elements of white slave tales. They both abandoned striving for a Victorian ideal of respectable femininity after the loss of their virginity and they were both exposed to a male threat due to their status as working women. Public spaces and the employment that thrust women out into the world made them vulnerable to immoral men even as poverty and poor wages were often cited by many prostitutes and reformers as the reason women entered the lifestyle. Cousins even mentioned poor parenting, a subject many reformers brought up, and a locked room, a scene often used in white slave narratives.

Another international source that can show how pervasive elements of the white slavery discourse were, are Canadian trial records. The Provincial Archives of Alberta contain important Supreme Court records that include cases of prostitution-related offenses. While, between 1900 and 1920, there were a number of women who were accused of prostitution, or being inmates or keepers of houses of ill repute, these were not cases explicitly linked to white slavery. Like the British moral tales, however, some accounts, especially those dealing with charges of "living off the avails of prostitution" or "procuring women", demonstrated the same vocabulary and once again blurred the lines between prostitution and white slavery. ${ }^{54}$

One such court case dealt with J.B. Fassett who was accused of taking advantage of his responsibility as guardian of seventeen year old orphan, Mamie Starr, and of living off her

\footnotetext{
${ }^{51}$ John Corry, The Gardener's Daughter of Worcester; or the Miseries of Seduction: A Moral Tale (London: Champagne and Whitrow, ca. 1800).

${ }^{52}$ See Donovan, White Slave Crusades, 17.

${ }^{53}$ See Sheila Cousins, To Beg I am Ashamed: The Autobiography of a London Prostitute (Paris: Obelisk Press, 1938).

${ }^{54}$ For further discussion on early twentieth-century prostitution in Edmonton, Alberta, see Piali Das Gupta, "Well Within the Margins: Prostitutes in Edmonton, 1904-1939" (master's thesis, University of Alberta, 1996).
} 
prostitution. ${ }^{55}$ This case hints at financial and emotional coercion but is far from the violent white slave story which often involved drugged drinks and locked rooms. Charges of procurement also offer insight into the spectrum of coercion that was involved in any prostitution case. The moral character of the women involved in these cases, like in the tales of white slavery, are of central importance to the courts. Some girls, for example, were described by the courts as "not being common prostitutes, nor of known immoral character". ${ }^{56}$ A reputation, good or bad, could be the difference between being protected by the legal system and being charged.

While still not a case that makes mention of human trafficking, Walter Griffiths, on February 28th, 1913, was charged with procuring two girls under twenty-one years old, Ollie Scott and Ollie Crawford. Within her testimony, Crawford asserted that she had never slept with any other man before Griffiths, and that she had not known "anything about such a life before". Lawyers obsessed over the issue of whether or not, she was "a good girl".

The same issue was raised in relation to Ollie Scott, but here racial identity is also marked as important. Interestingly, when Scott was asked if Griffiths "was... of [her] own nationality", she responded "No White". ${ }^{57}$ Though the record was silent on what ethnicity, or race she was, this small exchange entails that she was not white, in any case. The question of how this influenced her case must be left unanswered. Other cases also raise issues of race, immigration and urbanisation. An eighteen year old girl of Polish and Ruthenian descent, Lilly Samoridna, had newly arrived in the city after leaving her family farm two months previously and was working as a chamber maid. Like many white slavery accounts, this highlighted the vulnerability and isolation of newly migrated working women. Though she refused to "take the fellows up to [her] room", a G.R. Herzer and his wife, Jennie Herzer, were charged with attempting to procure her and another chamber maid to work in a "Common Bawdy House". ${ }^{58}$ In another example, the case against Louis Prineo necessitated a French and an Italian interpreter. Louis Prineo was charged with procuring a prostitute and the testimony of Germaine Chiaberto, who brought the complaint, is full of the violent hints of coercion, threat, and rape. Mrs. Chiaberto, for example, explained on numerous occasions throughout her deposition, that the accused "forced his way into [her] bed", and that he "forced [her] to prostitution". ${ }^{59}$ Though not charged with white slavery per se, these cases demonstrated some of the same elements of the white slavery narratives. They diverged, however, in the fact that less emphasis is placed on the racialized threat of procurers and on the moral purity of white women."White slavery", as a constructed term, policed boundaries of sexuality and race to a much larger extent than "prostitution" did. Even if the testimonies in these prostitution cases recall violence, physical threat and manipulation, they remain linked to but still apart from American white slave cases. ${ }^{60}$

\footnotetext{
${ }^{55}$ PAA, 83.1/3073 (Old Series), living on avails, Feb 4, 1913.

${ }^{56}$ PAA, 83.1/ 3045 (Old Series), procuring a prostitute, Feb 28, 1913.

${ }^{57}$ PAA, 83.1/3045 (Old Series), procuring a prostitute, Feb 28, 1913.

${ }^{58}$ PAA, 83.1/3005 (Old Series), procuring a prostitute, Jan 22, 1913.

${ }^{59}$ PAA, 83.1/3269 (Old Series), Sept 1, 1913.

${ }^{60}$ For other examples, see PAA, 83.1/3078 (Old Series), attempting to procure a prostitute, Mar 18, 1913; PAA, 83.1/1067 (Old Series), prostitution, Mar 8, 1907; Most cases, however, provide little contextual information because prostitutes and madams often pleaded guilty and paid the fine with little argument. See, for example, PAA, 83.1/1167 (Old Series), keeper of house of ill fame, Aug 22, 1907; PAA, 83.1/1085 (Old Series), prostitutes, Apr 2, 1907.
} 
While court cases, and moral tracts from other countries can help illuminate what is discovered in newspaper accounts, the specific case of Progressive Era America was particular in its manifestation of fears about coercive prostitution. Analyzing the discourse of white slavery, especially in relation to the construction of appropriate female behavior and the isolation of white purity in contrast to the threat of racial or ethnic minorities, can help uncover larger reasons why there was such fear surrounding this issue. Though many reformers may have been sincerely concerned about the welfare of innocent girls and women, the white slavery debate was co-opted by many interest groups for different reasons, among them morality reformers, politicians, the police and prostitutes themselves. It was used to encourage "cleaning up" the cities of moral improprieties, not only in the vice districts, but also in city hall, as was the case with Tammany Hall. It was used to discourage interracial relationships and to deport undesirable immigrants. For example, the persecution of Jack Johnson was an indictment against his relationships with white women. It was used to discuss larger fears of changing sexual norms, especially among the working class, and fears of women's employment and increased mobility in public. It was used to condemn industrial working conditions and wages, as seen by Jane Addams' writings. And, by the women themselves, it was used to claim the possibility of moral redemption. Within these networks of meaning, it is obvious that the issue of white slavery was much larger than, at first glance, it seems. Even the narrowest definition of the white slave trade as the international traffic of women coercively induced into prostitution, raises questions related to immigration policy and the role of the state in the protection of women. Within newspaper articles, reform tracts, morality tales and court cases, the construction of white slavery can be traced as a socio-political concern. Within the language are embedded assumptions about gender and race, about the construction of women and the construction of whiteness. Between 1900 and 1920, in the rapidly changing context of American cities, "white slavery" was a fluid term used to represent many manifestations of prostitution and to, as a result, institute control over women's bodies.

\section{Bibliography}

\section{Primary Sources}

\section{Archives}

Bruce Peel Special Collections Library. University of Alberta, Edmonton.

Provincial Archives of Alberta, Edmonton.

Supreme Court of Alberta Criminal Division Records. Accession 83.1, 1904-1939.

\section{Books}

Addams, Jane. A New Conscience and an Ancient Evil. New York: The Macmillan Company, 1914.

Cousins, Sheila. To Beg I am Ashamed: The Autobiography of a London Prostitute. Paris: Obelisk Press, 1938. 
Corry, John. The Gardener's Daughter of Worcester; or the Miseries of Seduction: A Moral Tale. London: Champagne and Whitrow, ca. 1800.

Goldman, Emma. "The Traffic in Women." In The Traffic in Women and Other Essays on

Feminism, edited by Alix Kates Shulman, 19-32. New York: Times Change Press, 1970.

Wilson, Woodrow. "Reconstruction." In A History of the American People. Vol.5, Reunion and Nationalization, 1-114. New York: Harper \& Brothers Publishers, 1902.

\section{M.A. Thesis}

Das Gupta, Piali. "Well Within the Margins: Prostitutes in Edmonton, 1904-1939." $\quad$ Master's Thesis, University of Alberta, 1996. Proquest (ID 304282779).

\section{Newspapers}

Edmonton Daily Bulletin.

Los Angeles Herald.

San Francisco Call.

New York Times.

\section{Secondary Sources}

\section{Articles}

Ambrosius, Lloyd E. "Woodrow Wilson and The Birth of a Nation: American Democracy and International Relations." Diplomacy and Statecraft 18, no.4 (2007): 689-718. doi. 10.1080/09592290701807168 (accessed December 12, 2012).

Beer, Janet, and Katherine Joslin. "Diseases of the Body Politic: White Slavery in Jane Addams' "A New Conscience and an Ancient Evil" and Selected Short Stories by Charlotte Perkins Gilman." Journal of American Studies 33, no. 1 (April 1999): 1- 18. http://www.jstor.org/stable/27556532 (accessed November 4, 2012).

Diffee, Christopher. "Sex and the City: The White Slavery Scare and Social Governance in the Progressive Era." American Quarterly 57, no. 2 (June 2005): 411-437. http://www.jstor.org/stable/40068272 (accessed November 4, 2012).

Donovan, Brian, and Tori Barnes-Brus. "Narratives of Sexual Consent and Coercion: Forced Prostitution Trials in Progressive-Era New York City." Law \& Social Inquiry 36, no. 3 (June 2011): 597-619. doi: 10.1111/j1747-4469.2011.01244.x （accessed September 25, 2012). 
Keire, Mara. "The Vice Trust: A Reinterpretation of the White Slavery Scare in the United States, 1907-1917." Journal of Social History 35, no. 1 (Autumn 2001): 5- 41. http://www.jstor.org/stable/3789262 (accessed November 11, 2012).

Lui, Mary Ting Yi. "Saving Young Girls from Chinatown: White Slavery and Woman Suffrage, 1910-1920." Journal of the History of Sexuality 18, no. 3 (September 2009): 393-417. doi: 10.2307/20542730 (accessed November 12, 2012).

Shumsky, Neil Larry. "Tacit Acceptance: Respectable Americans and Segregated Prostitution, 1870-1910." Journal of Social History 19, no. 4 (Summer 1986): 665-679. http://www.jstor.org/stable/3787983 (accessed October 25, 2012).

Stinchcombe, Arthur L., and Laura Beth Nielsen. "Consent to Sex: The Liberal Paradigm Reformulated." Journal of Political Philosophy 17, no. 1 (March 2009): 66-89. doi: 10.1111/j.1467-9760.2008.00306.x (accessed December 13, 2012).

\section{Books}

Blair, Cynthia M. I've Got to Make My Livin': Black Women's Sex Work in Turn of the Century Chicago. Chicago: University of Chicago Press, 2010.

Clement, Elizabeth Alice. Love for Sale: Courting, Treating, and Prostitution in New York City, 1900-1945. Chapel Hill: University of North Carolina Press, 2006.

Cordasco, Francesco, and Thomas Monroe Pitkin. The White Slave Trade and the Immigrants: A Chapter in American Social History. Michigan: Blaine Ethridge Books, 1981.

Donovan, Brian. White Slave Crusades: Race, Gender, and Anti-Vice Activism, 1887-1917. Chicago: University of Illinois Press, 2006.

Piott, Steven L. Daily Life in the Progressive Era. Oxford: Greenwood Press, 2011.

Pivar, David J. Purity Crusade: Sexual Morality and Social Control, 1868-1900. London: Greenwood Press, 1973.

Rosen, Ruth. The Lost Sisterhood: Prostitution in America, 1900-1918. London: The John Hopkins University Press, 1982.

Shulman, Alix Kates. "The Most Dangerous Woman in the World." In The Traffic in Women and Other Essays on Feminism, 5-15. New York: Times Change Press, 1970.

Stearn, Jess. Sisters of the Night: The Startling Story of Prostitution in New York Today. New York: Gramercy Publishing Company, 1956. 
Stokes, Melvyn. D.W. Griffith's The Birth of a Nation: A History of "The Most Controversial Motion Picture of All Time". Oxford: Oxford University Press, 2007. 